\title{
PENGARUH PENDIDIKAN GIZI TERHADAP PENGETAHUAN DAN PRAKTIK MEMBAWA BEKAL MENU SEIMBANG ANAK SEKOLAH DASAR
}

\author{
Effect of Nutrition Education on Knowledge and Practice in Bringing a Balanced Meal Box \\ among School Aged Children
}

\author{
Adelwais Febriati Yurni ${ }^{1}$, Tiurma Sinaga ${ }^{2}$ \\ ${ }^{1}$ Mahasiswa Departemen Gizi Masyarakat, Fakultas Ekologi Manusia, Institut Pertanian Bogor, Bogor \\ ${ }^{2}$ Dosen Departemen Gizi Masyarakat, Fakultas Ekologi Manusia, Institut Pertanian Bogor, Bogor
}

\begin{abstract}
ABSTRAK
Penelitian ini bertujuan untuk menganalisis pengaruh pendidikan gizi terhadap pengetahuan dan praktik membawa bekal menu seimbang (BMS) pada anak sekolah dasar. Desain penelitian adalah quasy experimental design with one group pre and post-test. Subyek penelitian sebanyak 52 siswa kelas 5 SDN Babakan Dramaga 04, Kabupaten Bogor. Intervensi pendidikan gizi dilakukan sebanyak 2 kali selama 2 minggu. Post-test 1 pengetahuan gizi seimbang dilakukan 1 minggu setelah intervensi, sedangkan post-test 1 praktik membawa BMS dilaksanakan 2 minggu setelah intervensi. Post-test 2 dan post-test 3 praktik BMS dilakukan setiap 2 minggu sekali. Pengukuran antropometri yang dilakukan adalah berat badan dan tinggi badan. Hasil penelitian menunjukkan bahwa pengetahuan gizi seimbang subyek meningkat setelah diberikan intervensi pendidikan gizi. Subyek juga menunjukkan adanya perbaikan praktik membawa bekal menu seimbang setelah intervensi. Hasil penelitian ini merekomendasikan praktik membawa bekal menu seimbang perlu dilanjutkan dan dipantau oleh guru olahraga. Orang tua, khususnya ibu sebaiknya mendukung siswa dengan menyediakan makanan seimbang.
\end{abstract}

Kata kunci: bekal anak sekolah, pendidikan gizi, pengetahuan gizi, menu seimbang

\section{ABSTRACT}

This study aims to analyze the effect of nutrition education on knowledge and practice of bringing a balanced meal box among school-aged children. The study design was quasy experimental design with one group pre and post-test. Subjects are 52 students of grade 5 at SDN Babakan Dramaga 04, Bogor District. Nutrition education was done twice for 2 weeks. Post-test 1 nutritional knowledge was done 1 week after intervention, and practice of bringing balance meal box was done 2 weeks after intervention. Post-test 2 and post-test 3 practice of bringing balance meal box was conducted every 2 weeks. Anthropometri measurement were weight and height. The results showed that knowledge of balanced nutrition increased after receive nutrition education. Subject show an improvement in the practice of bringing balance meal box after nutrition education intervention. This study recommend the school to continue asking the student to bring balance meal box, and monitored by sport teacher. Parents should support students by providing a balanced and nutritious food.

Keywords: school children meal box, nutrition education, nutritional knowledge, balance menu

\section{PENDAHULUAN}

Pola makan anak usia sekolah cenderung tinggi makanan jajanan dan rendah buah dan sayuran (Almatsier et al., 2011). Penelitian yang dilakukan oleh Amalia et al. (2012) menunjukkan bahwa jajanan yang paling sering dikonsumsi anak sekolah adalah makanan digoreng, minuman, dan kue, sedangkan buah dikonsumsi dengan frekuensi rendah.
Data Riset Kesehatan Dasar (Riskesdas) tahun 2010 menunjukkan bahwa sebesar 41,2\% anak usia sekolah di Indonesia mengonsumsi energi di bawah kebutuhan minimal, yaitu $<70 \%$ Angka Kecukupan Gizi (AKG). Kondisi ini dapat berdampak pada terjadinya wasting pada anak. Berdasarkan Riskesdas tahun 2013, sebesar $11,2 \%$ anak usia 5-12 tahun di Indonesia mengalami wasting. Selain wasting, prevalensi obesitas pada anak usia 5-12 
tahun juga tergolong tinggi, yaitu sebesar 18,8\%. Provinsi Jawa Barat, memiliki prevalensi gizi lebih dan gizi kurang pada anak usia 5-12 tahun sebesar 18,6\% dan 9,1\%. Prevalensi di Kabupaten Bogor sebesar 17,2\% dan 7,8\% (Kemenkes RI, 2013). Hal ini membuktikan bahwa beban gizi ganda masih dihadapi Indonesia.

Salah satu cara untuk mengurangi permasalahan gizi ganda ialah dengan pedoman gizi seimbang atau balanced nutrition guidelines. Pedoman gizi seimbang disusun untuk menyempurnakan 4 sehat 5 sempurna. Hal ini dikarenakan slogan 4 sehat 5 sempurna tidak sesuai dengan kondisi dan permasalahan gizi saat ini (Kemenkes, 2014).

Pedoman gizi seimbang perlu diperkenalkan kepada anak-anak. Salah satu cara yang dapat dilakukan ialah dengan pendidikan gizi. Hasil penelitian Februhartanthy (2005) membuktikan bahwa pendidikan gizi yang dilakukan pada anak usia sekolah efektif untuk mengubah pengetahuan dan sikap terhadap makanan. Anak usia sekolah lebih mudah untuk mengubah perilaku dibandingkan dengan orang dewasa. Pendidikan gizi yang diberikan diharapkan dapat meningkatkan pengetahuan anak usia sekolah dasar mengenai pedoman gizi seimbang. Pengetahuan akan memengaruhi sikap dan praktik gizi seimbang dalam keseharian. Praktik gizi seimbang diharapkan dapat mengurangi masalah gizi di kalangan anak. Hal ini dapat dilihat dari praktik makan anak sehari-hari. Salah satu upaya memantau praktik makan anak adalah School feeding program. School feeding sudah diterapkan dan diperhatikan penyelenggaraannya di negara maju. Indonesia belum menerapkan School feeding di semua sekolah, sehingga praktik gizi diamati dari bekal menu seimbang yang dibawa anak ke sekolah.

Pendidikan pedoman gizi seimbang pada anak sekolah dilakukan agar dapat mencetak generasi penerus bangsa yang berkualitas. Penting pula untuk menanamkan paradigma baru menggantikan paradigma 4 sehat 5 sempurna yang sudah tidak sesuai dengan permasalahan yang dihadapi saat ini. Paradigma tersebut ialah pedoman gizi seimbang yang harus dipraktikkan dalam kehidupan seharihari. Penelitian ini bertujuan untuk menganalisis pengaruh pendidikan gizi terhadap pengetahuan dan praktik membawa bekal menu seimbang anak sekolah dasar.

\section{METODE}

\section{Desain, Waktu, dan Tempat Penelitian}

Penelitian dilakukan dengan menggunakan desain quasy experimental design with one group pre and post test. Penelitian ini dilaksanakan di SD Negeri Babakan Dramaga 04, Dramaga, Bogor Barat. Pemilihan lokasi penelitian dilakukan secara purposive dengan pertimbangan bahwa tidak ada penyelenggaraan makanan di sekolah. Penelitian dilaksanakan pada Februari-April 2017. Penelitian dilakukan pada saat jam pelajaran olahraga. Berdasarkan pengamatan, anak sekolah akan pergi ke kantin setelah olahraga. Hal ini menyebabkan anak sekolah cenderung mengonsumsi lebih banyak makanan ketika selesai melakukan olahraga, sehingga dengan dilakukannya penelitian ini diharapkan anak sekolah akan mengonsumsi makanan yang lebih sehat, yaitu bekal menu seimbang.

\section{Jumlah dan Cara Penarikan Sampel}

Sampel penelitian adalah siswa SD kelas 5. Sampel dipilih berdasarkan kriteria inklusi: siswa laki-laki dan perempuan kelas 5, masuk sekolah saat sedang dilakukan penelitian, bersedia menjadi sampel penelitian dan kriteria eksklusi: minimal 1 kali tidak membawa bekal. Berdasarkan perhitungan rumus Slovin, jumlah minimal sampel penelitian sebanyak 52 anak. Penelitian ini menggunakan sampel sebanyak 52 anak dari 108 anak kelas 5 SD.

\section{Intervensi Pendidikan Gizi dan Prosedur Penelitian}

Intervensi pendidikan gizi seimbang dilakukan selama 2 minggu sebanyak 2 kali pertemuan setiap kelasnya di ruangan yang telah disediakan. Durasi satu kali pertemuan adalah 30-45 menit. Materi pendidikan gizi berisi mengenai pengenalan zat gizi dan porsi makanan dalam sehari, aneka ragam makanan, perilaku hidup bersih dan sehat, olahraga atau aktifitas fisik, serta memantau berat badan. 
Metode yang dilakukan berupa ceramah dan diskusi. Intervensi menggunakan media poster, buku cerita bergambar, lagu "4 pilar gizi seimbang" dan "ayo mencuci tangan", serta kartu bergambar. Gambar 1 menyajikan tahapan penelitian yang dilakukan.

Uji coba kuesioner pengetahuan gizi seimbang (uji validitas dan realibilitas)

$$
\downarrow
$$

Pengambilan data awal (karakteristik subyek, karakteristik sosial ekonomi keluarga, dan pengukuran antropometri)$$
\downarrow
$$

Pre-test pengetahuan gizi seimbang

$$
\downarrow
$$

Pre-test praktik membawa bekal menu seimbang

$$
\downarrow
$$

Intervensi pendidikan gizi seimbang (2 kali selama 2 minggu)

$$
\downarrow
$$

Post-test 1 pengetahuan gizi seimbang

$$
\downarrow
$$

Post-test 1 praktik membawa bekal menu seimbang. Subyek yang belum membawa bekal sesuai menu seimbang diberikan konseling gizi

$$
\downarrow(2 \text { minggu })
$$

Post-test 2 praktik membawa bekal menu seimbang. Subyek yang belum membawa bekal sesuai menu seimbang diberikan konseling gizi

$$
\downarrow \text { (2 minggu) }
$$

Post-test 3 praktik membawa bekal menu seimbang. Subyek yang belum membawa bekal sesuai menu seimbang diberikan konseling gizi

$$
\downarrow
$$

Post-test 2 pengetahuan gizi seimbang$$
\downarrow
$$

Pengecekan seluruh data dan variabel

$$
\downarrow
$$

Penginputan data $\downarrow$

Pengolahan data dan pembahasan

Gambar 1. Prosedur penelitian

\section{Metode Pengumpulan dan Pengolahan Data}

Pengetahuan diperoleh melalui self administered questionnaire yang terdiri dari 14 pertanyaan. Setiap pertanyaan dengan jawaban benar diberikan skor 1 dan jawaban salah diberi skor 0 . Skor maksimal yang dapat diperoleh adalah 100. Skor pengetahuan kemudian diklasifikasikan menjadi baik jika skor $>80$, sedang jika skor $60-80$, dan kurang jika skor $<60$ (Khomsan, 2000).

Praktik membawa bekal menu seimbang dinilai melalui kesesuaian dengan visual Piring Makanku. Terdapat 2 aspek penilaian yang dilakukan, yaitu keanekaragaman makanan dan jumlah atau porsi makanan yang dibawa. Praktik dikategorikan menjadi dua, yaitu sesuai, jika bekal makanan beranekaragam dengan porsi yang tepat berdasarkan Piring Makanku dan tidak sesuai jika tidak memenuhi anjuran Piring Makanku.

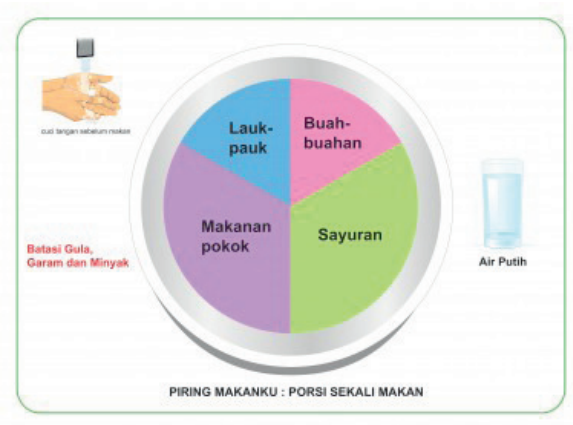

Gambar 2. Piring Makanku Sumber: Kemenkes (2014)

Status gizi dinilai secara antropometri menggunakan indikator indeks massa tubuh menurut umur (IMT/U). Tinggi badan subyek diukur dengan menggunakan stature meter yang memiliki kapasitas maksimum pengukuran $200 \mathrm{~cm}$ dan ketelitian $0,1 \mathrm{~cm}$. Berat badan subyek diukur menggunakan timbangan digital merek Camry dengan kapasitas maksimum pengukuran $150 \mathrm{~kg}$ dan ketelitian $0,1 \mathrm{~kg}$. Status gizi diklasifikasikan menjadi sangat kurus (z-score $<-3,0 \mathrm{SD}$ ), kurus $(-3,0 \mathrm{SD} \leq \mathrm{z}$-score $<-2,0 \mathrm{SD})$, normal $(-2,0 \mathrm{SD}<$ $\mathrm{z}$-score $<1,0 \mathrm{SD})$, gemuk $(1,0 \mathrm{SD}<\mathrm{z}$-score $<2,0$ $\mathrm{SD})$, sangat gemuk (z-score $>2,0 \mathrm{SD}$ ) menurut klasifikasi Kemenkes (2013). 
Data asupan gizi diperoleh dari makanan yang dikonsumsi subyek, yang dikumpulkan melalui metode Recall $2 \times 24$ jam dan metode Food Record. Data konsumsi diolah menjadi asupan energi dan zat gizi dengan cara mengalikan berat makanan, kandungan energi dan zat gizi dalam makanan, serta berat dapat dimakan makanan tersebut. Asupan energi dan zat gizi kemudian dikonversi menjadi kecukupan energy dan zat gizi dengan menghitung persentase pemenuhan terhadap angka kecukupan energi dan zat gizi. Perbedaan antara variabel sebelum dan sesudah intervensi dianalisis menggunakan paired simple t-test.

\section{HASIL DAN PEMBAHASAN}

\section{Karakteristik Subyek}

Subyek berusia antara 10-12 tahun dengan rata-rata usia 10 tahun dan $67,3 \%$ di antaranya perempuan. Sebagian besar subyek $(53,8 \%)$ memiliki uang saku di atas rata-rata (Rp 9.714/ hari). Uang saku terbesar yang diberikan orang tua atau wali ialah $\mathrm{Rp} 30.000 /$ hari, sedangkan Rp 5.000/hari adalah uang saku yang paling kecil. Subyek membelanjakan $71 \%$ uang sakunya untuk pengeluaran pangan, yaitu jajan saat istirahat sekolah.

Sebanyak 50\% subyek berasal dari keluarga kecil dengan jumlah anggota keluarga kurang dari 4 orang. Semakin besar jumlah keluarga semakin banyak pula kebutuhan yang harus dipenuhi, khususnya kebutuhan pangan. Hal ini berarti semakin sedikit jumlah anggota keluarga semakin baik makanan terbagi dengan jenis dan porsi yang sesuai di keluarga tersebut. Tingkat pendidikan sebagian besar orang tua adalah tamat SMA/ sederajat. Pendidikan ibu berkaitan erat dengan status gizi anak (Abuya, et al., 2012). Ibu memiliki peranan yang penting dalam menyediakan dan menyajikan makanan bagi keluarga, khususnya anak. Sebanyak 40,4\% ayah bekerja sebagai wiraswasta, sedangkan ibu tidak bekerja (75\%). Ibu yang tidak bekerja memiliki waktu memadai untuk berinteraksi dengan anak, sehingga dapat meningkatkan kualitas pelayanan ibu (Pahlevi, 2012).

\section{Status Gizi}

Sebanyak 73,1\% subyek memiliki status gizi normal baik pre-test maupun post-test. Tabel 1 menunjukkan sebaran subyek berdasarkan status gizi.

Hasil studi Anindita (2014) menunjukkan tidak ada perubahan status gizi subyek selama 2 bulan penelitian, sedangkan hasil penelitian Nurmasyita et al. (2015) menunjukkan ada perbedaan indeks massa tubuh subyek sebelum dan sesudah intervensi pendidikan gizi setelah diberikan intervensi pendidikan gizi selama 3 bulan. Dengan demikian, lama pemberian pendidikan gizi memengaruhi perubahan status gizi pada subyek.

Tabel 1. Sebaran Subyek berdasarkan Status Gizi

\begin{tabular}{lcccc}
\hline \multirow{2}{*}{ Kategori } & \multicolumn{2}{c}{ Pre-test } & \multicolumn{2}{c}{ Post-test } \\
\cline { 2 - 5 } & $\mathbf{n}$ & $\mathbf{\%}$ & $\mathbf{n}$ & $\mathbf{\%}$ \\
\hline Sangat kurus & 0 & 0,0 & 0 & 0,0 \\
Kurus & 2 & 3,8 & 2 & 3,8 \\
Normal & 38 & 73,1 & 38 & 73,1 \\
Gemuk & 6 & 11,5 & 7 & 13,5 \\
Sangat gemuk & 6 & 11,5 & 5 & 9,6 \\
Total & 52 & 100 & 52 & 100 \\
Rata-rata \pm SD & $-0,14 \pm 1,46$ & \multicolumn{2}{c}{$-0,04 \pm 1,47$} \\
\hline
\end{tabular}

\section{Pengetahuan Gizi}

Setelah diberikan intervensi pendidikan gizi, pengetahuan subyek meningkat. Penelitian yang dilakukan oleh Dwiriani (2012) mengungkapkan bahwa peningkatan skor pengetahuan setelah intervensi pendidikan gizi belum tentu dapat memperbaiki praktik makan subyek. Gambar 3 menyajikan sebaran subyek berdasarkan kategori tingkat pengetahuan gizi sebelum dan sesudah diberikan intervensi pendidikan gizi.

Rata-rata skor pengetahuan gizi seimbang subyek meningkat dari pre-test ke post-test 1 dan menurun pada post-test 2, namun masih lebih tinggi dibandingkan pada pre-test. Rata-rata skor pengetahuan gizi seimbang pre-test, post-test 1 , dan post-test 2 masing-masing adalah 77,6 4 13,7; $83,9 \pm 10,0 ;$ dan $83,5 \pm 9,1$. 


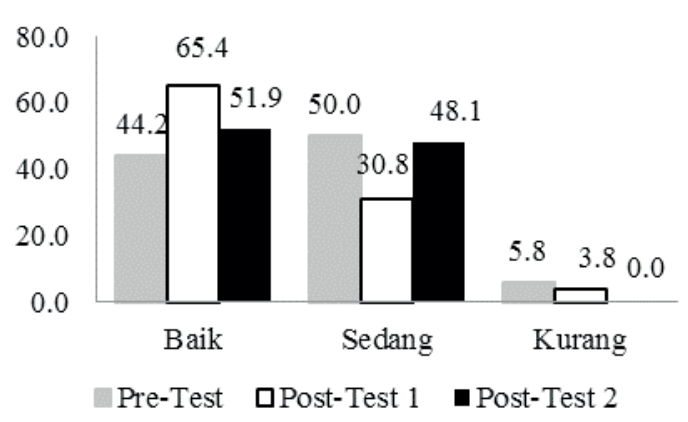

Gambar 3. Sebaran Subyek berdasarkan Kategori Tingkat Pengetahuan Gizi Sebelum dan Sesudah Intervensi

Hasil uji beda paired sample t-test menunjukkan adanya perbedaan skor pengetahuan antara pre-test dengan post-test $1(\mathrm{p}=0,003)$ dan post-test $2(\mathrm{p}=0,010)$. Penelitian sejenis lain memberikan hasil yang serupa, yaitu penelitian Zulaekah (2012) yang menunjukkan adanya peningkatan pengetahuan setelah intervensi menggunakan media animasi dan booklet. Penelitian yang dilakukan Marisa \& Nuryanto (2014) pada anak sekolah dasar di Semarang juga menunjukkan adanya peningkatan pengetahuan setelah diberikan pendidikan gizi dengan komik gizi seimbang. Nuryanto, et al. (2014) melakukan intervensi pendidikan gizi terhadap 2 SD di Semarang dan menunjukkan hasil yang berpengaruh terhadap pengetahuan anak sekolah dasar tentang gizi seimbang.

\section{Praktik Membawa Bekal Menu Seimbang}

Berdasarkan Gambar 4, terdapat perbaikan menu mulai dari pre-test, post-test 1 , dan post-test 2 . Menu yang dibawa oleh subyek adalah nasi dengan mie goreng, nasi goreng, dan nasi dengan lauk hewani, seperti ayam goreng dan telur dadar. Hanya 3,8\% subyek membawa buah dan 15,4\% subyek membawa sayuran. Hal ini menggambarkan praktik subyek terhadap pemilihan menu seimbang masih kurang.

Hasil penelitian Proverawati, et al. (2008) menunjukkan bahwa anak-anak cenderung menyukai makanan yang kaya akan karbohidrat dan protein hewani. Protein dibutuhkan untuk membantu proses tumbuh kembang anak. Porsi nasi yang dibawa belum sesuai dengan Piring

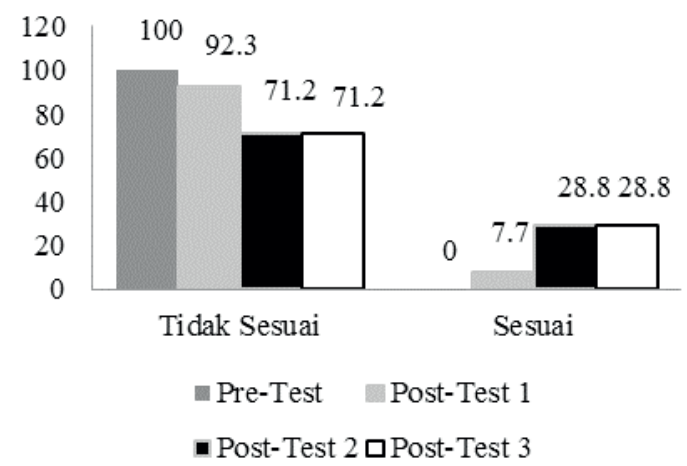

Gambar 4. Sebaran Subyek berdasarkan Praktik Membawa Bekal Menu Seimbang

Makanku. Sebagian besar subyek membawa nasi dengan porsi sama dengan besar kotak bekalnya. Setelah diberikan intervensi pendidikan gizi, terdapat $7,7 \%$ subyek membawa bekal menu seimbang sesuai dengan visual Piring Makanku.

Pada post-test 1 terjadi peningkatan jumlah subyek yang membawa buah, yaitu $11,5 \%$. Dalam sesi pendidikan gizi, pemateri memotivasi subyek untuk mengonsumsi buah dan sayur sesuai dengan porsi yang dianjurkan. Sinaga (2016) mengungkapkan bahwa motivasi yang kuat kepada subyek perlu dilakukan agar terjadi peningkatan konsumsi buah dan sayur. Lauk hewani $(73,1 \%)$ lebih banyak dikonsumsi subyek dibandingkan dengan lauk nabati $(21,2 \%)$. Sebanyak 15,4\% subyek membawa dan mengonsumsi sayuran pada post-test 1 . Porsi nasi lebih banyak dibandingkan porsi sayuran. Sayur yang dibawa subyek rata-rata sebanyak 1-2 centong sayur (20-25 g). Porsi lauk hewani rata-rata 1 potong untuk ayam goreng (45 g) dan 1 butir telur dadar (55 g). xPorsi buah adalah 1 buah jeruk (55 g), 1 potong besar pepaya $(110 \mathrm{~g})$, dan 1 buah pisang ambon $(60 \mathrm{~g})$.

Peningkatan kesesuaian antara bekal yang dibawa subyek dengan Piring Makanku pada posttest 2 sebesar $21,1 \%$. Subyek yang membawa sayur dan buah dalam bekal menu seimbang juga meningkat menjadi $40,4 \%$ dan $46,2 \%$. Sebanyak $82,7 \%$ subyek mengonsumsi lauk hewani. Beberapa subyek masih membawa bekal dengan menu nasi putih dan mie goreng. Porsi nasi, sayuran, lauk hewani, dan buah yang dibawa oleh subyek pada post-test 2 tidak berbeda dengan porsi bekal pada post-test 1 . Subyek mulai membawa lauk nabati 
Tabel 2. Asupan Zat Gizi dari Bekal Menu Makanan Seimbang

\begin{tabular}{|c|c|c|c|c|}
\hline Energi dan Zat Gizi & Pre-test & Post-test 1 & Post- Test 2 & Post-test 3 \\
\hline \multicolumn{5}{|l|}{ Energi } \\
\hline Asupan (kkal) & 577,8 & 454,1 & 476,7 & 526,0 \\
\hline$p$ value & & $0,000^{a}$ & $0,001^{b}$ & $0,094^{c}$ \\
\hline TKE $(\%)$ & 94,7 & 74,4 & 78,2 & 86,1 \\
\hline \multicolumn{5}{|l|}{ Protein } \\
\hline Asupan (g) & 17,7 & 16,0 & 17,2 & 18,5 \\
\hline$p$ value & & $0,158^{a}$ & $0,641^{b}$ & $0,573^{c}$ \\
\hline TKP (\%) & 98,3 & 90,9 & 97,6 & 99,1 \\
\hline \multicolumn{5}{|l|}{ Lemak } \\
\hline Asupan (g) & 23,8 & 17,1 & 18,2 & 20,6 \\
\hline$p$ value & & $0,001^{a}$ & $0,017^{b}$ & $0,189^{c}$ \\
\hline TKL (\%) & 35,1 & 25,2 & 26,8 & 30,3 \\
\hline \multicolumn{5}{|l|}{ Karbohidrat } \\
\hline Asupan (g) & 72,3 & 57,9 & 60,2 & 65,8 \\
\hline$p$ value & & $0,000^{a}$ & $0,006^{b}$ & $0,122^{c}$ \\
\hline TKKH (\%) & 47,4 & 38,0 & 39,6 & 43,2 \\
\hline \multicolumn{5}{|l|}{ Serat } \\
\hline Asupan (g) & 2,8 & 2,2 & 2,4 & 2,2 \\
\hline$p$ value & & $0,010^{a}$ & $0,125^{b}$ & $0,023^{c}$ \\
\hline
\end{tabular}

${ }^{\mathrm{a}}$ Hasil uji beda pre-test dengan post-test 1

${ }^{b}$ Hasil uji beda pre-test dengan post-test 2

${ }^{c}$ Hasil uji beda pre-test dengan post-test 3

dengan porsi 2 sendok makan tempe oreg ( $22 \mathrm{~g}$ ) dan 1-2 potong kecil tahu dan tempe goreng ( $25 \mathrm{~g}$ ).

Subyek yang membawa bekal sesuai dengan visual Piring Makanku tidak berubah dari posttest 2 ke post-test 3 . Konsumsi buah pada posttest 3 sebesar $40,4 \%$, sedangkan konsumsi sayuran mengalami peningkatan menjadi $55,8 \%$. Konsumsi buah dan sayur masih rendah pada anak sekolah dasar. Hasil ini sesuai dengan hasil penelitian Mohammad \& Madanijah (2015). Keanekaragaman menu bekal yang dibawa oleh subyek meningkat dari pre-test hingga post-test 3 , tetapi jumlah dan porsi dari menu tersebut belum mengalami perbaikan. Pendidikan gizi yang dilakukan oleh Owais, et al. (2017) selama 2 tahun dapat meningkatkan kualitas diet pada balita di Bangladesh. Penelitian Reinbott, et al. (2016) membuktikan bahwa pendidikan gizi selama 1 tahun dapat meningkatkan konsumsi makanan kaya akan beta karoten serta sayur dan buah. Dengan demikian, perbaikan jumlah dan porsi bekal menu seimbang belum meningkatkan dikarenakan pemberian pendidikan gizi yang terlalu singkat.

Sekolah menyediakan kantin agar mempermudah siswa dalam membeli makanan. Kantin sekolah masih menyediakan makanan jajanan yang tidak beraneka ragam. Tidak ada penjual buah potong atau jus buah di kantin sekolah. Berdasarkan pengamatan, kantin sekolah menjual makanan seperti jajanan semacam aneka chiki, gorengan, siomay, batagor, cilok, dan minuman dingin (es teh). Hal ini mengakibatkan subyek kurang konsumsi sayur dan buah.

Bekal menu seimbang yang dibawa oleh subyek memenuhi 20-25\% dari total makan sehari. Persentase ini sesuai untuk melengkapi kebutuhan sarapan sebesar 25\% (Khomsan, 2000). Subyek mengonsumsi bekal menu seimbang saat istirahat setelah jam pelajaran olahraga selesai, yaitu 10.30-11.00 WIB. Tabel 2 menyajikan asupan zat gizi dari bekal menu makanan seimbang yang dibawa oleh subyek. Hasil uji paired sampel t-test menunjukkan bahwa ada perbedaan signifikan 
antara asupan energi, lemak, karbohidrat, dan serat pada pre-test dengan post-test $1(\mathrm{p}<0,05)$.

Terdapat perbedaan antara asupan energi, lemak, dan karbohidrat pada pre-test dan post-test $2(\mathrm{P}<0,05)$. Tidak ada perbedaan antara asupan energi, protein, lemak, dan karbohidrat pada pre-test dengan post-test 3 ( $>>0,05)$, sedangkan terdapat perbedaan signifikan antara asupan serat pre-test dan post-test $3(\mathrm{p}<0,05)$.

Tingkat kecukupan protein subyek tinggi karena untuk mendukung pertumbuhan. Protein hewani lebih disukai dibanding dengan protein nabati. Sumber protein hewani adalah ayam, telur, dan ikan. Berdasarkan penelitian Simanjutak dan Hartono (2010) semakin tinggi konsumsi protein, semakin baik pula status gizi anak.

\section{KESIMPULAN DAN SARAN}

Pengetahuan gizi seimbang subyek meningkat setelah diberikan intervensi pendidikan gizi. Praktik membawa bekal menu seimbang juga membaik dari pre-test, post-test 1 , post-test 2 , dan post-test 3.

Orang tua, khususnya ibu sebaiknya mendukung siswa dengan menyediakan makanan yang seimbang. Praktik membawa bekal menu seimbang di sekolah sebaiknya dipantau oleh guru olahraga. Kantin sekolah perlu menyajikan makanan yang beragam dan bergizi seimbang. Hal ini diperlukan agar anak dapat memilih makanan yang sehat dan dapat mempertahankan pemilihan makanan hingga usia dewasa. Penelitian selanjutnya sebaiknya dilakukan intervensi pendidikan gizi dan observasi praktik membawa bekal menu seimbang dengan waktu yang lebih lama, yaitu lebih dari 1 bulan.

\section{DAFTAR PUSTAKA}

Abuya, B.A., Ciera, J., \& Kimani-Murage, E. (2012). Effect of mother's education on child's nutritional status in the slums of Nairobi. BMC Pediatrics, 12 (80), 1-10. Diakses dari https://bmcpediatr.biomedcentral.com/ articles/10.1186/1471-2431-12-80.
Almatsier, S., Soetardjo, S., \& Soekatri, M. (2011). Gizi seimbang dalam daur kehidupan. Jakarta (ID): PT. Gramedia Pustaka Utama.

Anindita, N. (2014). Pengaruh penyuluhan gizi terhadap pengetahuan, konsumsi pangan, dan status gizi siswa obesitas di SMPN 5 Bogor (Skripsi tidak dipublikasikan). Institut Pertanian Bogor, Bogor, Indonesia.

Amalia, L., Endro, O.P., \& Damanik, R.M. (2012). Preferensi dan frekuensi konsumsi makanan jajanan pada anak sekolah dasar di Kecamatan Cijeruk, Kabupaten Bogor. Jurnal Gizi dan Pangan, 7(2), 119-126. Diakses dari journal.ipb.ac.id/index.php/jgizipangan/article/ view/12374.

Dwiriani, C.M. (2012). Pengaruh pemberian zat multi gizi mikro dan pendidikan gizi terhadap perilaku makan dan status besi remaja siswi SMP (Disertasi tidak diterbitkan). Sekolah Pascasarjana, Institut Pertanian Bogor, Bogor, Indonesia.

Februhartanthy, J. (2005). Nutrition education: It has never been an easy case for Indonesia. Food and nutrition bulletin, 26(2), 267-274. Diakses dari https://www.ncbi.nlm.nih.gov/ pubmed/16075577.

[Kemenkes] Kementerian Kesehatan. (2014). Peraturan Menteri Kesehatan Republik Indonesia Nomor 14 Tahun 2014 tentang pedoman gizi seimbang. Jakarta (ID): Direktorat Jendral Bina Gizi dan Kesehatan Ibu dan Anak.

[Kemenkes] Kementerian Kesehatan. (2013). Laporan hasil riset kesehatan nasional 2013. Jakarta (ID): Badan Penelitian dan Pengembangan Kesehatan. Kementerian Kesehatan RI.

Khomsan A. (2000). Pangan dan gizi untuk kesehatan 2. Bogor: Departemen Gizi Masyarakat, Fakultas Ekologi Manusia, Institut Pertanian Bogor.

Marisa \& Nuryanto. (2014). Pengaruh pendidikan gizi melalui komik gizi seimbang terhadap pengetahuan dan sikap pada siswa SDN Bendungan di Semarang. Journal of Nutrition College. 3(4), 925-932. Diakses dari http:// id.portalgaruda.org/index.php?ref=browse\&m od=viewarticle $\&$ article $=270607$. 
Mohammad, A. \& Madanijah, S. (2015). Konsumsi buah dan sayur anak usia sekolah dasar di Bogor. Jurnal Gizi dan Pangan, 10(1), 71-76. Diakses dari http://journal.ipb.ac.id/index.php/ jgizipangan/article/view/9315.

Nurmasyita, Widjarnako, B., \& Margawati, A. (2015). Pengaruh intervensi pendidikan gizi terhadap peningkatan pengetahuan gizi perubahan asupan zat gizi, dan indeks massa tubuh remaja kelebihan berat badan. Jurnal Gizi Indonesia, 4(1), 38-47. Diakses dari https:// ejournal.undip.ac.id/index.php/jgi/article/ view/12326.

Nuryanto, Pramono A., Puruhita, N., \& Muis S.F. (2014). Pengaruh pendidikan gizi terhadap pengetahuan dan sikap tentang gizi anak sekolah dasar. Jurnal Gizi Indonesia, 3(1), 32-36. Diakses dari https://ejournal.undip.ac.id/index. php/jgi/article/view/8751/7080.

Owais, A., Schwartz, B., Kleinbaum D.G., Suchdev PS, Faruque A.S.G., Das S.K., Rahman S., \& Stein, A. (2017). A nutrition education program in rural Bangladesh was associated with improved feeding practice but not with child growth. American Society for Nutrition, 147(5), 948-954. Diakses dari https://www.ncbi.nlm. nih.gov/pubmed/28298543.

Pahlevi, A.E. (2012). Determinan status gizi pada siswa sekolah dasar. Kesmas, 7(2), 122-126. Diakses dari https://journal.unnes.ac.id/artikel_ nju/kemas/2807.
Proverawati, A., Prawirohartono, E., \& Kunjjoro, T. (2008). Jenis kelamin, pendidikan ibu, dan motivasi dari guru serta hubungannya dengan preferensi makan sekolah pada anak prasekolah di TK Universitas Muhammadiyah Purwokerto. Jurnal Gizi Klinik Indonesia, 5(2), 78-83. Diakses dari http://www.ingentaconnect.com/ content/doaj/1693900x/2008/00000005/00000 002/art00004.

Reinbott, A., Schelling, A., Kuchenbecker, J., Herrmann, J., Jeremias, T., Russell, I., Kevanna, O., Jordan, I., \& Krawinkel, M.B. (2016). Oneyear nutrition education intervention improves dietary diversity but not stunting among children aged 6 to 23 months in rural Cambodia. Di dalam: Effectiveness of a Nutrition Education Intervention to Improves Complementary Feeding Practices (Unpublished Doctor's thesis). VVB Laufersweiler Verlag, Germany.

Sinaga, T. (2016). Gizi anak sekolah. Di dalam: Hardinsyah \& Supariasa IDN. Ilmu gizi teori dan aplikasi. Jakarta (ID): EGC.

Simanjutak, G. \& Hartono, A.S. (2010). Konsumsi makanan jajanan, konsumsi makanan di rumah dan status gizi anak di SDN 04 Petang, Jakarta Timur. Nutrire Diaita, 2(1), 1-8. Diakses dari http://ejurnal.esaunggul.ac.id/index.php/ Nutrire/article/view/664.

Zulaekah, S. (2012). Efektifitas pendidikan gizi dengan media booklet terhadap pengetahuan gizi anak SD. Jurnal Kesehatan Masyarakat, 7(2), 121-128. Diakses dari https://journal. unnes.ac.id/artikel_nju/kemas/1771. 